\title{
Book Review: Universities and Regional Development: A Critical Assessment of Tensions and Contradictions
}

\author{
Edited by Rómulo Pinheiro, Paul Benneworth and Glen A. Jones. \\ London and New York: Routledge, 2014. 265 pp. \\ ISBN: 978-0-415-89355-8.
}

This book about the "third mission" of universities explains that higher education institutions are under increasing pressure to promote innovations, entrepreneurship, economic growth and welfare in their local communities. The book presents three stylized university models: (1) the research-intensive university, (2) the regional university, and (3) the entrepreneurial university. The pressure these institutions experience provides an opportunity for a paradigm shift to develop traditional research-oriented and regionally-oriented universities into entrepreneurial universities.

The research-intensive universities are based on the oldfashioned Humboldt's reforms in Germany in the early nineteenth century, which changed purely educational universities into an alternative model focusing on research alongside teaching. The main characteristics of these universities include a disciplinary orientation in research and education, scientific autonomy, and internationally connected and nationally embedded activities. The top-down steering of universities is weak, and the internal orientation is collegial. The regional engagement of the researchintensive universities is also weak.

Regional universities were established grounded on specialized institutions, and they are teaching-centered based on professional and vocational training. The academic core of regional universities was particularly weak during the first decades. The internal orientation, with top-down management and a professional core, is strong in comparison with researchintensive universities. Regionally-oriented education is relevant and has a strong periphery in regional universities. Education is nationally connected and regionally embedded.

Entrepreneurial universities such as the Massachusetts Institute of Technology benefit from interdisciplinary collaboration combining science and technology. Teaching, research, and service have a strong nexus, and the entrepreneurial universities have a strong academic core. The entrepreneurial universities have executive management with a top-down internal orientation. Their activities are based on partnerships, and user orientation is strong in research. The entrepreneurial universities are globally engaged but locally responsive.

The main obstacles faced by research-intensive universities are academic autonomy, collegial management, ranking systems, and internal research, which reduce their external impact on the region. These features guide the staff of research universities to write scientific papers with minor external impacts on the region. Research-intensive universities have a natural tendency to actively resist change, usually seeking to protect their core activities from external disturbances. Research-intensive universities develop knowledge and competencies internally, so that the researcher can be the first presenter of the new knowledge. However, this kind of closed activity, without strategic innovation alliances and communities, is unable to create a competitive advantage for business companies in the region. When research-intensive universities are not able to clearly show their external impact on the region, they emphasize the long-term social welfare of graduates and the society as a whole, which is not in balance with short-term regional interests.

Public policy has sought to enhance the impact of researchintensive universities as sites of knowledge creation and thereby to realize the socio-economic value of publicly funded research. The book reveals internal tensions surrounding the allocation of resources between traditional tasks (e.g., teaching and research) and more peripheral endeavors (e.g., social outreach, consultancy and innovation) to promote regional development. The book also presents case studies that highlight the dilemmas associated with the clash between academic norms, values and priorities on the one hand, and the strategic goals and agendas of external stakeholders such as regional industry, on the other.

The book does not focus on the establishment of the universities of applied sciences that can be seen as a paradigm shift to boost regional development. The main challenge of these regional universities is the weak research core, which is still regulated in many European countries by their competitors. Research-intensive universities have jurisdiction to limit the 
number of doctor's degrees of the universities of applied sciences that have no doctoral education. That is supported by the national education policy, which favors research-intensive universities even though the universities of applied sciences are more valuable from the regional development perspective.

The research core of the regional universities of applied sciences has become stronger because the European Union and many other sources have provided funding for applied research and development. Budget cuts have forced regional universities to develop strategies for encouraging and facilitating engagement with the regional economy. This has led to changes in the legislation of the universities of applied sciences, especially in Finland, where the applied research and development to support regional development were added to the mission of these institutions in 2003. The weak regional core of the universities of applied sciences can be improved by harmonizing the legislation of research-intensive and regional universities and by allocating more research funding for regional universities to promote regionally embedded research and development.

The entrepreneurial university provides a development scenario for the universities of applied sciences that are regional universities and that aim for more research-oriented activities. The "academic drift" of the universities of applied sciences has shifted from a nuisance to a virtue, a situation where applied research, development and innovation activities support regional development. The universities of applied sciences respond to the interdisciplinary development needs of the region with a strong applied academic core, executive management and partnerships, and thus they become more valuable than the research-intensive universities from the perspective of regional development. The book provides an excellent development route and vision for the regional universities.

The book sheds new light on the ignorance of the ways in which regional bodies have viewed higher education and in which scholars of higher education have traditionally viewed the region and the third mission of higher education institutions. The book explores the third mission using empirical case studies from Europe, the Americas, Africa and Asia. The entrepreneurial university represents a comprehensive and theoretically grounded framework tracing different internal challenges faced by researchintensive universities. The universities of applied sciences are moving towards the model of entrepreneurial universities, which provides them with a challenging vision for a better future.

Reviewed by Juha Kettunen

Turku University of Applied Sciences, Finland 